Босевська Л. П., Хрущов Д. П.

Український науково-дослідний інститут соляної промисловості (УкрНДІсіль) Інститут геологічних наук Національної академї̈ наук Украӥни

\title{
НАДЗВИЧАЙНА ЕКОЛОГІЧНА СИТУАЦІЯ В СОЛОТВИНО: ГЕОЛОГІЧНІ ПРИЧИНИ І СТРАТЕГІЯ РОЗВ'ЯЗАННЯ ПРОБЛЕМИ
}

Надане наукове геологічне тлумачення причин створення надзвичайної екологічної ситуації на території Солотвинського родовища кам'яної солі та запропоновані стратегічні напрямки вирішення проблеми.

Ключові слова: соляний масив, соляний карст, солерудник, екологічна обстановка.

Дано научное геологическое толкование причин создания чрезвычайной экологической ситуации на территории Солотвинского месторождения каменной соли и предложены стратегические направления решения проблемы.

Ключевые слова: соляной массив, соляной карст, солерудник, экологическая обстановка.

Scientific geological interpretation of reasons of the created Solotvino rock-salt deposit extraordinary ecological situation had been expounded. Strategic directions of decision of problem had been offered.

Key words: Hydrochloric file, salt karst, salt mine, ecological situation

Постановка i актуальність проблеми. Останніми роками на Солотвинському родовищі кам'яної солі виникла надзвичайна екологічна ситуація, результатом чого стала втрата діючих шахт, повна аварійна зупинка роботи солевидобувного підприємства, деградація ландшафту, виникнення дестабілізованого рельєфу, розвиток величезних проваль навіть за межами гірничого відводу діючих шахт, а також припинення функціонування унікального підземного відділення спелеосанаторію Української алергологічної лікарні (УАЛ), діяльність якого була пов'язана з гірничими виробками шахт.

Екологічна катастрофа у смт. Солотвино привернула увагу громадськості та ЗМІ України, оскільки вона за масштабами та соціальноекономічними наслідками набула загальнодержавного значення. Соціальні напруження спричинили певну реакцію урядових структур, що знайшло відображення у відповідному дорученні Президента України В. Ф. Януковича і залученні до вирішення проблеми Міністерства надзвичайних ситуацій $[4,7]$. У грудні 2010 р. на засіданні Закарпатської обласної комісії 3 питань техногенно-екологічної безпеки та надзвичайних ситуацій прийнято рішення класифікувати ситуацію, що виникла на Солотвинському родовищі кам'яної солі та на прилеглій території, як геологічну надзвичайну. Підгрунтям для вирішення проблеми та визначення напрямків іiї вирішення може бути лише наукове геологічне тлумачення причин створення надзвичайної ситуації, яке до цього часу ще остаточно не сформульоване.

Мета статті - надання загальної професійної експертної оцінки реального стану Солотвинського масиву, визначення причин створення 
надзвичайної ситуації та позначення стратегічних напрямків поводження 3 деградованою територією.

Автори статті представляють науковий творчий колектив, що спеціалізується на вирішеннях проблем соляної геології на базі новітніх світових досягнень в області вивчення функціональних властивостей соляного середовища

( ) Л. П. Босевська, Д. П. Хрущов, 2011

Сучасний стан об'єкту й історична довідка. Солотвинське родовище являє собою діапіровий купол первинної баденської соленосної формації неогену, розташований геологічно - в межах Карпатського внутрішнього прогину [3], геоморфологічно - в межах алювіальних терас транскордонної p. Тиса, адміністративно - в Тячівському районі Закарпатської області, в смт. Солотвино (рис.1).
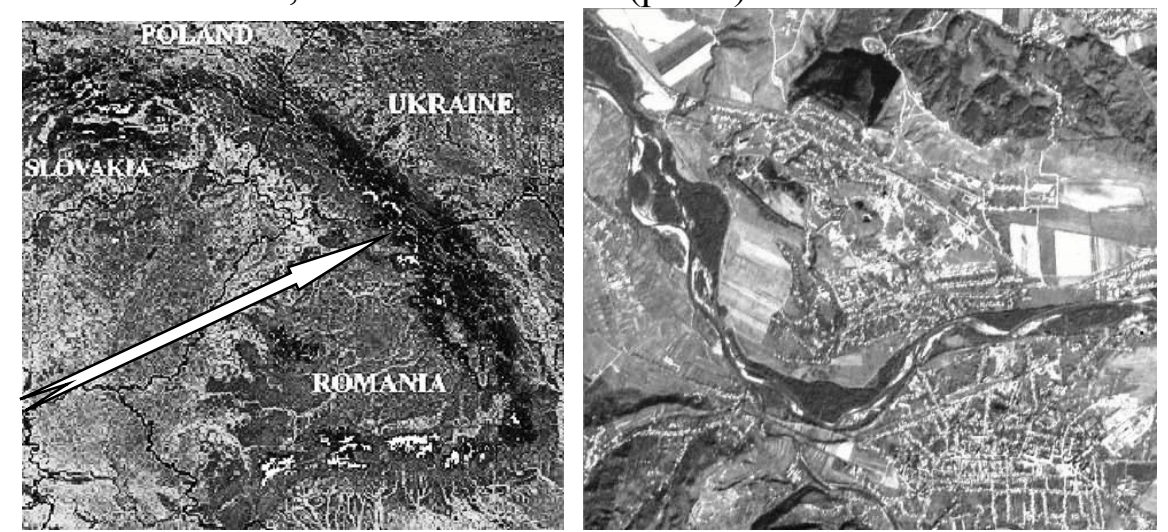

Рис.1. Положення Солотвинської структури в Карпатському внутрішньому прогині в межах заплавної та надзаплавних терас р. Тиси. Аерофотознімки.

Згідно архівним даним, Солотвинське родовище експлуатується підземним шляхом понад 220 років. На родовищі в різні часи діяли 9 шахт, до останнього часу - шахти № 8 та № 9, 3 діяльністю яких, власне, і пов'язаний розвиток екологічно небезпечної ситуації (табл. 1). У розвиток руйнівних процесів була затягнута також центральна ділянка соляного масиву, що містить затоплені виробки шахти № 7. Всі сім старих шахт були закриті раніше з кон'юнктурних та технічних (аварійних) причин, і їх стан до останнього часу визначався як екологічно врівноважений, оскільки вони були своєчасно законсервовані шляхом засипки або затоплення (природного, штучного чи комбінованого).

Шахта № 7, що припинила свою діяльність в 1953 р., внаслідок порушення верхнього водозахисного цілика (рис.2, 3) має два горизонти загальним об'ємом 1,7 млн. $\mathcal{M}^{3}$, стельовий цілик $30-45$ м і розкриває соляний масив до глибини 220 м (абс. відм. +75,0 м). Шахта експлуатувалася при постійних надходженнях води та мала 5 рівнів дренажних виробок, що свідчить про те, що центральна частина родовища до глибини до 100 м була зруйнована техногенним карстом. Гідравлічний зв'язок виробок шахти із 
старими виробками через соляний масив був доведений ще Б. Ульріхом. Водовідливна система, що функціонувала на шахті, стимулювала інтенсивний техногенний карст $[1,2,6,11,12]$, і ще у 1950-ті рр. названа була фахівцями соляної галузі «порочною» [3].

Шахта № 8 існує вже 125 років, експлуатаційні роботи тут проводились до 2007 року. Шахта має чотири відпрацьовані горизонти загальним об'ємом близько 8 млн. м $^{3}$, був підготовлений до експлуатації п’ятий горизонт. Висота камер варіює від 45 м для верхнього горизонту до 65 м - для нижнього, при цьому товщина ціликів між експлуатаційними горизонтами близько 20 м. Перший горизонт цієї шахти також був закладений невдало з точки зору потужності верхнього запобіжного цілика (до 40 м). Функціонування шахти відбувалося при постійному функціонуванні розгалуженої дренажної системи i при постійному збільшенні надходжень вод. 
Загальні відомості про шахти, які були створені за весь період підземної експлуатації Солотвинського родовища кам'яної солі

\begin{tabular}{|c|c|c|c|c|c|c|c|}
\hline $\begin{array}{l}\text { № } \\
\Pi / \Pi\end{array}$ & $\begin{array}{l}\text { Назва шахт } \\
\text { та їх номер }\end{array}$ & $\begin{array}{c}\text { Ділянка } \\
\text { родовища }\end{array}$ & $\begin{array}{l}\text { Початок } \\
\text { експлуата } \\
\text { ціï, рік }\end{array}$ & $\begin{array}{l}\text { Припинення } \\
\text { експлуатації }\end{array}$ & $\begin{array}{l}\text { Абс. відм. } \\
\text { підошви } \\
\text { виробок }\end{array}$ & $\begin{array}{c}\text { Рік } \\
\text { ліквідації }\end{array}$ & Причини ліквідації і спосіб \\
\hline 1 & Христина, №1 & \multirow{5}{*}{ 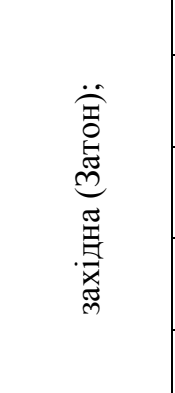 } & 1778 & 1781 & невідомо & невідомо & низька якість солі; засипаний грунтом \\
\hline 2 & Альберт, №2 & & 1781 & 1789 & $\begin{array}{r}\text { близько } \\
+200 \mathrm{M} \\
\end{array}$ & до 1870 & $\begin{array}{c}\text { прорив води через обвалення покрівлі; } \\
\text { природне затоплення }\end{array}$ \\
\hline 3 & Кунігунда ${ }^{1}$, №3 & & 1789 & 1905 & $+138 \mathrm{M}$ & 1925 & $\begin{array}{c}\text { прорив води через обвалення покрівлі; природне } \\
\text { затоплення; пізніше засипаний грунтом }\end{array}$ \\
\hline 4 & Микола, №4 & & 1789 & 1905 & $+110 \mathrm{M}$ & 1925 & $\begin{array}{c}\text { прорив води через обвалення покрівлі; природне } \\
\text { затоплення, пізніше засипаний грунтом }\end{array}$ \\
\hline 5 & Йосип, №5 & & 1804 & 1850 & невідомо & 1895 & низька якість солі; природне затоплення \\
\hline 6 & Старий Людвіг, №6 & ПдС & 1804 & 1810 & $+207 \mathrm{M}$ & 1930 & низька якість солі; часткова засипка грунтом \\
\hline 7 & Франтішек, №7 & центр & 1809 & 1953 & $+75,8$ & 1970 & $\begin{array}{c}\text { послаблення опорних і міжгоризонтного ціликів, } \\
\text { обвалення покрівлі камери, прорив води; } \\
\text { комбіноване затоплення (природне і частково } \\
\text { штучне) } \\
\end{array}$ \\
\hline 8 & Новий Людвіг, №8 & ПдС & 1886 & 2007 & $-85 \mathrm{M}$ & $\begin{array}{r}\text { експлуат } \\
\text { аварій } \\
\text { зат }\end{array}$ & $\begin{array}{l}\text { ційні роботи не проводяться з } 2006 \text { р. внаслідок } \\
\text { ого стану та складних гідрогеологічних умов; } \\
\text { плюється; знаходиться в стадії консервації }\end{array}$ \\
\hline 9 & №9 & $\begin{array}{c}\text { Пн крило } \\
\text { куполу }\end{array}$ & 1975 & 2008 & -146 м & 2010 & $\begin{array}{c}\text { прорив води; глибинний техногенний соляний } \\
\text { карст, карстово-суфозійні процеси; } \\
\text { природне затоплення }\end{array}$ \\
\hline
\end{tabular}

' В подальшому шахти «Кунігунда» і «Микола» були об’єднані, відомі як об’єднана шахта «Кунігунда - Микола» 


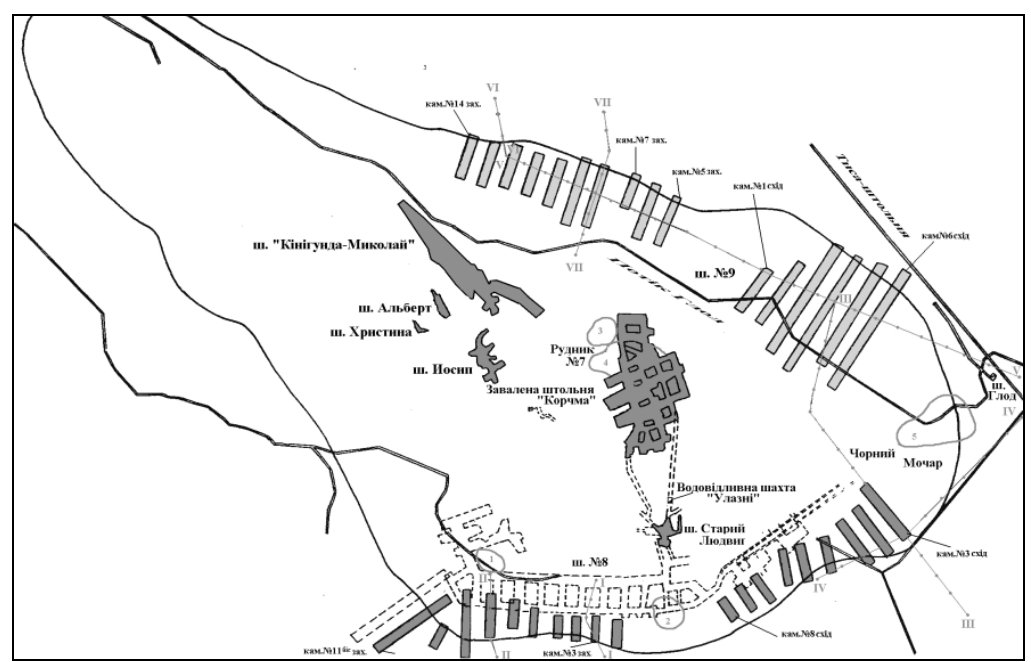

Рис. 2. Схема розташування шахт на Солотвинському родовищі 3 позначенням найбільших карстових проваль

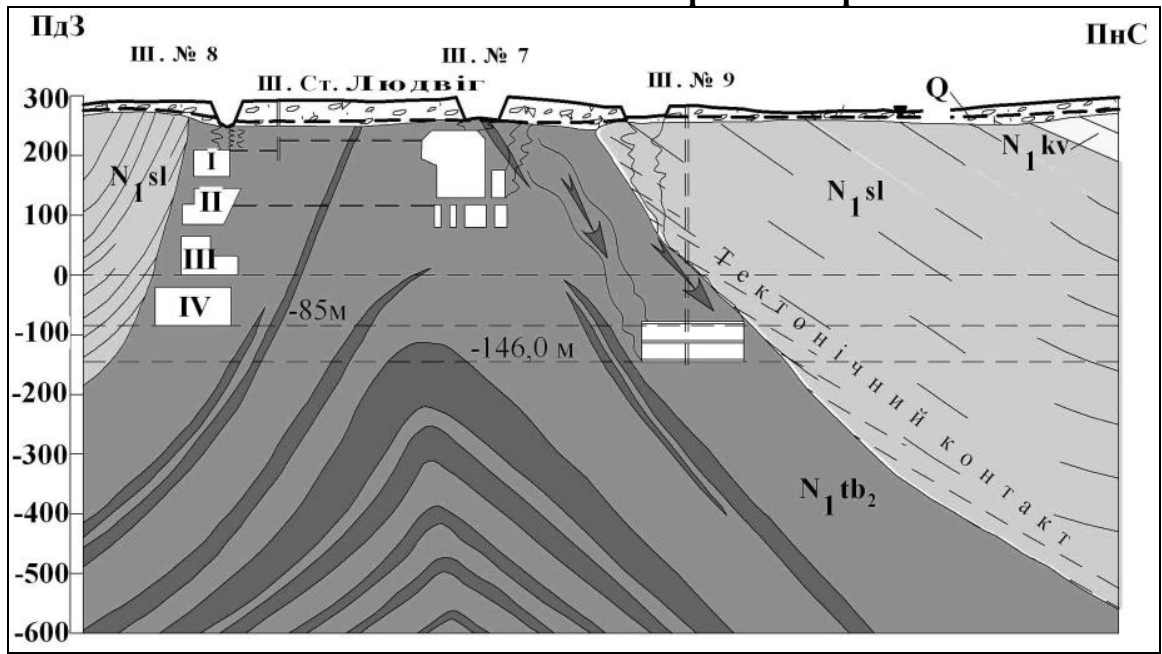

Рис. 3. Схематичний розріз через центральну частину Солотвинського родовища. Стрілкою показані шляхи надходження вод в шахту № 9 через водопроникні шари

Перший крупний прорив води відбувся у 1999 році і спричинив затоплення підготовлених до експлуатації виробок V горизонту. 3 цього часу значні надходження води, в тому числі й «аварійні прориви», стали постійними. Так, з 2000 р. сумарні надходження води до шахти збільшилися $340 \mathrm{~m}^{3} /$ год до $300 \mathrm{~m}^{3} /$ год на теперішній час. При цьому найбільш інтенсивні руйнівні процеси в масиві порід над гірничими виробками спостерігалися на ділянках скупчення дренажних виробок, діяльність яких i провокувала найбільш небезпечні його деформації. Карстові процеси ускладнювалися карстово-суфозійними, і наслідком їх інтенсифікації стало руйнування у декількох місцях стельових ціликів та формування величезних проваль на поверхні, які постійно розвиваються до цього часу. Руйнування поверхні на цей час має катастрофічний, непрогнозований характер, надходження вод за останні 3 роки збільшилося з $160 \mathrm{~m}^{3} /$ доб до 320 і більше. 
Шахта № 9 була закладена на глибині 430 м, діяла в інтервалі часу 1975 - 2007 pр. і мала один відпрацьований горизонт на абс. відм. - 146,0 м. Параметри системи розробки: ширина міжкамерних ціликів варіює у рамках 30 - 46 м, довжина камер - $100-300$ м при висоті 68 м. Відпрацьований шахтою підземний простір складає за об'ємом близько 4 млн. м $^{3}$. Вище експлуатаційного горизонту було розміщене підземне відділення УАЛ, яке було пов'язане 3 виробками шахти стовбурами. Західна частина шахтного поля експлуатувалася в задовільних умовах, а на східному фланзі шахти практично з самого початку спостерігалися надходження води, при цьому вони були приурочені до окремих прошарків солі з підвищеною вологістю (рис. 4). Надходження води (розсолів) 32000 р. почало збільшуватись надзвичайно великими темпами, і в 2006 р. склало близько $200 \mathrm{~m}^{3} /$ год, а в 2008 р. - понад $550 \mathrm{~m}^{3} /$ год. Шахтні води постійно відкачувалися, при цьому мінералізація вод, що відкачувалися, була на межі повного насичення понад 300 г/л, тобто води, що надходили, тривалий час вилуговували соляний масив. Наслідки цього - інтенсифікація глибинного карстоутворення і небезпечного нерівномірного осідання земної поверхні, розвиток карстових проваль, деформація поверхні на проммайданчику шахти i відповідне руйнування шахтних споруд. Безпосередньо на проммайданчику було утворено дві карстові вирви. На теперішній час шахта повністю затоплена, заповнені водою карстові порожнини над шахтою, рівень води над шахтою знаходиться у рівновазі з рівнем підземних вод.

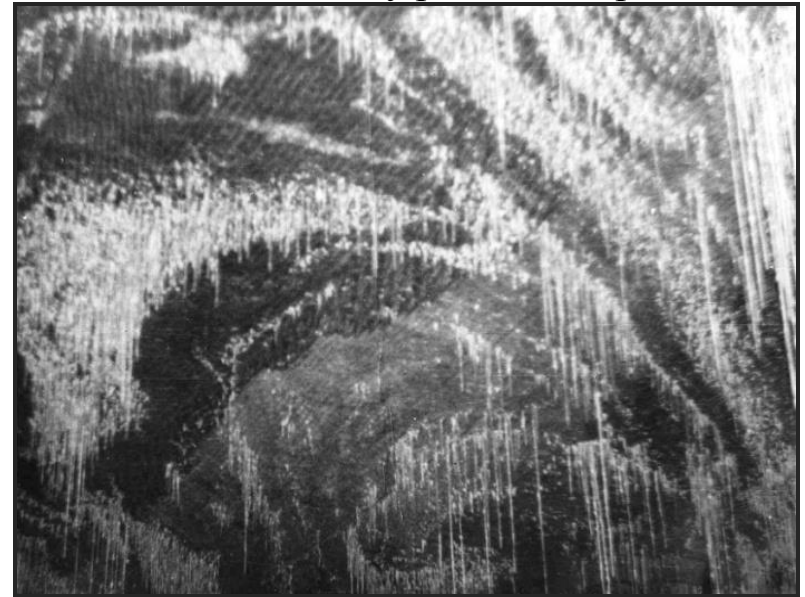

Рис. 4. Виділення розсолів із водопроникних шарів кам'яної солі на північно-східній ділянці куполу.

Гор. -112,0 м ш. № 9 (гл. 400 м). Фото 1987 р. (матеріали УкрНДІсіль)

Фактично надзвичайну ситуацію сформувало послідовне руйнування соляного масиву в зонах впливу кожної 3 шахт, які поступово розширювалися по латералі та поєднувалися з відповідними деформаціями надсольових порід і рельєфу земної поверхні. Масштабність некерованих карстових процесів підтверджує той факт, що на протязі останніх двох років практично вся поверхня над соляним тілом прийшла до руху, - до процесів руйнувань поверхні були залучені навіть ділянки, під якими немає гірничих виробок. 
Причини екологічної дестабілізації. Визначення причин i механізмів розвитку катастрофічних процесів у соляному геологічному середовищі становить основу для визначення стратегічних технічних рішень щодо поводження з об'єктом.

Солотвинська солянокупольна структура первісно відзначалася задовільною природною захищеністю соляного тіла ${ }^{2} .3$ п'яти встановлених градацій цей рівень досить невисокий, проте він дозволяв структурі існувати в геологічному часі протягом кількох сотень тисяч років, 3 початку голоцену. Система природної захищеності Солотвинського соляного тіла включає два елементи: кепрок (глинистий шар, або так званий «палаг») потужністю від $20-30$ см до $10-20$ м і зону насичених розсолів [3]. Така невитриманість зумовлює первісну нерівномірність захищеності соляного тіла. Певну захисну роль відіграють також інші покривні породи, але вони представлені четвертинними алювіальними утвореннями 3 гарними фільтраційними властивостями (гальковик, валуни, глина, пісок), і до них приурочені надсольові водоносні горизонти терас р. Тиси. В результаті техногенного втручання i розвитку масштабного карсту 3 порушенням гірського масиву і земної поверхні на теперішній час природна захищеність соляного тіла у значному ступеню знищена.

Зона захисних розсолів формується на контакті надсольового горизонту із соляним тілом i фактично являе собою нижню частину зонального за мінералізацією водоносного горизонту. Горизонт розсолів виконує захисну функцію лише в стабільних гідрогеологічних умовах, але в даному випадку надсольовий водоносний горизонт по зовнішній межі періодично підпирається водами прилягаючої заплавної тераси р. Тиси, частково - напірними водами горизонтів оточуючих осадових товщ. Така гідрогеологічна ситуація зумовлює рухливість контурів розсільної зони, тобто вразливість їі захисних властивостей.

Підсистема внутрішньої захищеності соляного масиву включає наявність елементів його внутрішньої структури 3 різною здатністю протистояти проникненню агресивних вод. Згідно проведеній попередніми роботами літологічній структуризації Солотвинської соляної товщі були визначені типи кам'яної солі з підвищеною проникністю, яка обумовлюється природною пустотністю [9]. До таких ділянок віднесені брекчійовані зони, структурно-літологічні типи соляної породи 3 підвищеною тріщинуватістю, 3 відкритою пористістю, 3 ознаками незавершеної перекристалізації. Розкриття таких зон гірничими виробками, якщо вони пов'язані структурними елементами породношарового рівня із зоною розповсюдження агресивних вод, стає причиною утворення умов для карсту і каналів проникнення вод. Загальна схема механізму соляного карсту в разі розкриття таких зон показана численними роботами, і розвиток глибинного

2 Під терміном «захищеність соляних товщ» автори розуміють забезпеченість їх системою гідравлічних бар'єрів в уміщуючому геологічному середовищі по відношенню до існуючих або потенційних джерел агресивних підземних вод [8] 
техногенного карсту Солотвинського масиву $є$ ще однією ілюстрацією класичної схеми розвитку соляного карсту з утворенням значної кількості карстових порожнин в соляному масиві $[1-3,5,6,11,12]$.

Передумовою створення масштабного карсту $є$ забезпечення руху агресивних вод та видалення насичених розсолів. Саме цю роль виконувала поширена водовідливна та дренажна система, яка була створена в декілька рівнів у самому соляному масиві для забезпечення можливості проведення гірничих робіт.

На певному етапі при розростанні карстових порожнин процес доповнювався карстово-суфозійними явищами, тобто надходженням мас уламкового матеріалу. При переході певних геомеханічних порогів почали відбуватися вивали порід із збільшенням об'ємів новоутворених порожнин, що в кінцевому рахунку спровокувало втрату гірським масивом стійкості на всю потужність до земної поверхні [2]. Всі ці процеси і явища в різних масштабах в різні часи відбувались на різних ділянках Солотвинського родовища.

На основі наведеного механізму карстоутворення можна визначити причини утворення надзвичайної екологічної ситуації сьогодення як тотальне порушення зовнішньої захищеності соляного тіла при незадовільній внутрішній захищеності окремих ділянок соляного тіла (наявності водопроникних шарів з крутим падінням).

1. У підсистемі зовнішньої захищеності в експлуатаційному процесі були порушені два діючі елементи: водотриви і зони захисних розсолів. Основний водотрив (шар «палагу») фактично втратив свої захисні властивості через значну його порушеність внаслідок розвитку провальних явищ. Несанкціонована розробка гальковику над соляним тілом та забудова поверхні також значно знизили зовнішню захищеність. Порушення зони розсолів спричиняється мінливими гідродинамічними умовами в процесі розвитку масштабного карсту. Визначальним фактором руху вертикальних руйнівних потоків агресивних вод є відкритий глибинний базис дренажу. Над соляним тілом існує надсольовий рухливий агресивний водоносний горизонт 3 високими фільтраційними властивостями. Запаси вод горизонту безперервно поповнюються 3 періодичними піковими зростаннями. Для обмеження надходження цих вод була побудована розгалужена система контурного i локального дренажу, водоперехоплення й відливу, але ефективними були лише елементи контурного дренажу (Тиса-штольня), які були створені поза межами соляного масиву, і перехоплювали підземний потік ще до його контакту із соляним тілом. Інші елементи дренажної і водовідливної систем лише прискорювали розвиток карсту [2, 3].

2. Внутрішня захищеність соляного тіла і створюваних порожнин визначається структурно-літологічним фактором, якому до останнього часу не приділялося уваги. Базовими академічними дослідженнями останніх двох десятиліть доведено, що функціональні властивості соляного масиву (міцнісні, фільтраційні, технологічні, захисні тощо) обумовлюються, перш за все, літологічними особливостями соляних порід [5, 6, 9 -12]. Саме наявність 
літотипів соляної породи із незадовільними функціональними характеристиками, розкритими виробками, при певних умовах стає причиною розвитку карсту із негативними соціально-економічними та екологічними. На теперішній час створена структурно-літологічна модель родовища [9], яка продовжує удосконалюватися. Створена модель дозволяє чітко визначити, що Солотвинська соляна товща у своєму складі містить ділянки із різними функціональними властивостями, перерозподіл яких у просторі регулюється внутрішньою структурно-літологічною будовою куполу. В основі створеної моделі полягає літологічна структуризація соляного масиву, згідно якій визначено 10 функціональних типів кам'яної солі. Аналіз створеної моделі дозволяє констатувати, що приповерхнева частина соляного куполу містить значні об'єми соляної породи підвищеної проникності (розвинута мікротріщинуватість як результат стародавнього вивітрювання тощо) до глибин, що варіюють для різних ділянок масиву від 50 до 100 і більше метрів. В межах північно-східної ділянки родовища визначена пачка соляної породи 3 підвищеною проникністю та послабленими фізико-механічними показниками [8], на значні глибини (щонайменше до 500 м). Ця пачка, розкрита східною частиною шахтного поля шахти № 9, різко відрізняється за структурно-літологічними особливостями від інших частин соляного тіла. Вона представлена значно забрудненою кам'яною солі із ознаками незавершеної перекристалізації, що обумовило послаблені міжзернові зв'язки, відкриту пористість, значну кількість первинних седиментаційних розсолів, приурочених до окремих прошарків (див. рис. 3, рис.4, 5).

Неврахування механізму розвитку карсту i впливу на нього особливостей внутрішньої будови соляного масиву стало причиною помилкової стратегії науково-дослідних робіт, що проводились останніми роками на родовищі.

Виходячи $з$ наведеного, можливо констатувати, що термін дії кожної шахти і їі вплив на розвиток загальних порушень соляного масиву був первісно визначений просторовим розташуванням іiі виробок відносно водопроникних ділянок масиву та ступенем початкової порушеності масиву, що відпрацьовувався.

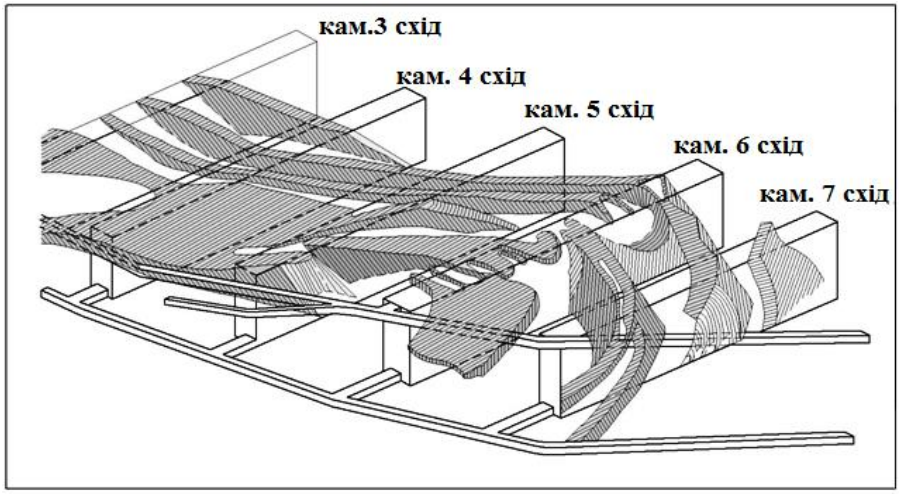

Рис. 5. Шари водопроникної кам'яної солі на північно-східній ділянці соляного куполу (за результатами картування східної частини шахтного поля шахти № 9 УкрНДІсіль) 


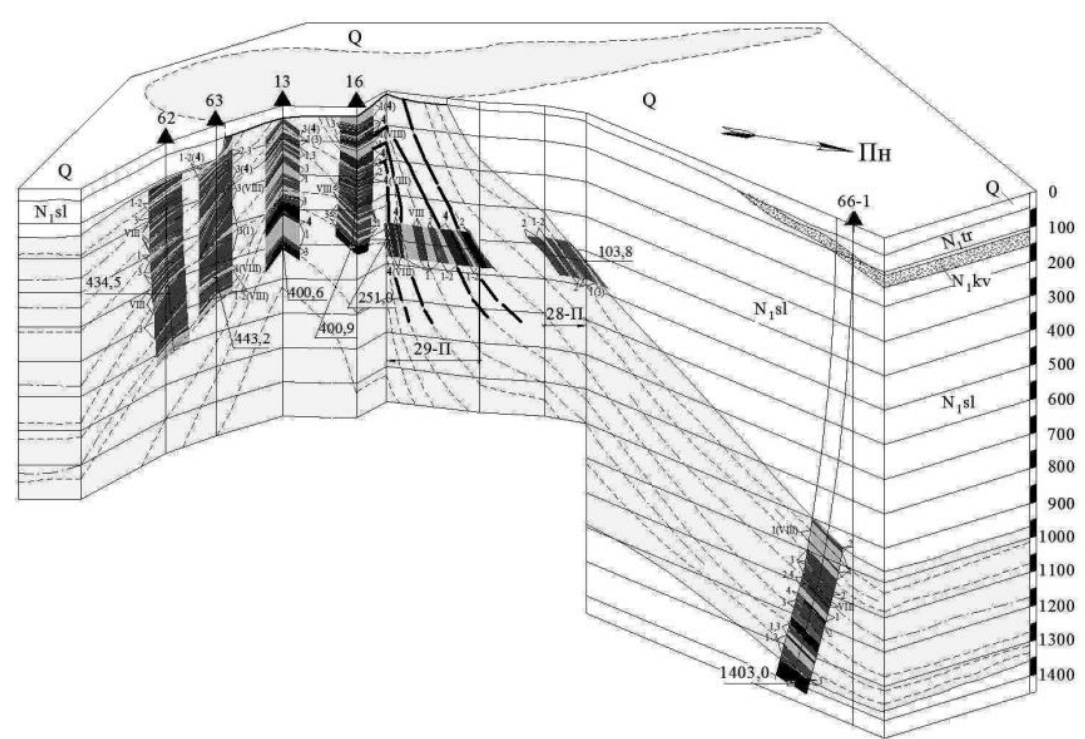

Рис. 6. Фрагмент структурно-літологічної моделі північно-східної частини Солотвинського соляного куполу. Показані шари кам'яної солі із незадовільними функціональними властивостями (водопроникні).

Так, шахта № 7 розташована на ділянці із розвитком задовільних функціональних типів соляної породи, внаслідок чого шахта існувала найдовше в історії підземної експлуатації родовища. Припинення роботи шахти відбулося внаслідок взаємодії геомеханічного (руйнування стельового цілика) та гідрогеологічного факторів (початок розвитку карсту).

Шахта № 8 розташована переважно у межах розповсюдження сприятливих функціональних типів кам'яної солі, але I горизонт закладений дуже близько до поверхні, у межах незахищеної зони (вивітрілої), внаслідок чого тотально зруйнований стельовий цілик шахти, що стало причиною остаточного затоплення шахти і зробило неможливим вжиття будь-яких технічних заходів внаслідок втрати земною поверхнею стійкості. Цьому також сприяло функціонування численних елементів локального дренажу в межах стельового цілику та у самому соляному масиві. Припинити негативні процеси можливо було лише своєчасною ліквідацією I горизонту шляхом засипки, як це пропонувалося ще у 80-ті роки.

Шахта № 9 західним крилом розкрила камяну сіль сприятливих функціональних типів, але східним - потужний шар слабозцементованої солі, який виходив під крутим кутом падіння безпосередньо до інтенсивно вивітрілої та закарстованої зони в центральній приповерховій частині родовища. Тому через певний час після проходки виробок на цій ділянці почався розвиток карсту згідно класичній схемі з формуванням масштабної гідрогеологічної депресії, яка охопила більшу частину родовища $\mathrm{i}$ інтенсифікувала руйнівні процеси на всіх ділянках приповерхової частини родовища. Ситуація швидко стала неконтрольованою, і втрата шахти стала неминучою. Затоплення шахти відбулося за період з травня 2007 р. до грудня 2008 р. Процес затоплення супроводжувався катастрофічними порушеннями геологічного середовища. 
Наведені вище дані свідчать, що розвиток деструктивних процесів на території об'єкту досяг катастрофічних масштабів, і це показує на економічну недоцільність і технічну неможливість відновлення безпечної роботи шахт. На теперішній час шахта № 9 вже затоплена, відбувається мимовільне природне затоплення виробок шахти № 8, що провокує подальший розвиток руйнівних явищ. Обмеження розвитку карсту i пов'язаних з ним деструктивних явищ може бути лише остаточна ліквідація глибинного базису дренажу шляхом повного затоплення останньої незатопленої шахти № 8. Тривалий час на різних рівнях вирішувалися питання щодо можливості подовження терміну роботи шахт і підземних відділень УАЛ в той час, коли зупинити техногенний карст, який обійняв значну частину масиву, вже було неможливо, - при активній дії визначених вище причин i показаному ступеню розвитку карсту усі заходи $\epsilon$ недоцільними і навіть небезпечними з технічної та екологічної точок зору, не кажучи вже про економічну обтяжливість.

Результатом втрати часу $є$ значний розвиток техногенезу соляного масиву, безповоротна втрата значної частини запасів соляної сировини, і ця втрата має тенденцію до подальшої експансії, поки не завершиться затоплення останньої з діючих соляних шахт.

Стратегічні пріоритети поводження 3 геологічним середовищем Солотвинського родовища $\mathrm{i}$ перспективні напрямки вирішення екологічних, виробничих і соціальних проблем визначаються на основі наведених вище результатів оцінки стану соляного середовища. Вони дозволяють сформулювати концептуальне визначення стратегічних напрямків розв'язання всіх проблем, що виникли в результаті надзвичайної екологічної ситуації на території смт. Солотвино. Після завершення ліквідації шахти № 8 шляхом затоплення гірничих виробок будуть забезпечені передумови певного призупинення розвитку карсту, але карстоутворення триватиме ще до повної стабілізації гідрогеологічної обстановки. Зробити повний прогноз можливо лише на основі комплексної оцінки остаточного стану соляного масиву після затоплення всіх виробок за гідрогеологічним та геомеханічним критеріями.

На наступних етапах буде необхідним здійснення додаткових заходів, спрямованих на обмеження розвитку деструктивних явищ, пов'язаних 3 карстом. В числі першочергових завдань має бути забезпечення вимог соціальних напружень, спричинених небезпекою поверхневих деформацій для громадських забудов у зоні впливу вказаних виробок. Обгрунтування необхідних і достатніх заходів має базуватись на даних прогнозної карти розвитку карсту, яка складається з урахуванням визначеної оцінки соляного середовища.

Рішення соціальних проблем, насамперед, передбачає відродження використання соляного середовища, бо втрата виробництва соляної продукції, а особливо спелеосанаторію УАЛ, для Солотвино означає істотну соціальну деградацію. 
Для розв'язання цих завдань необхідно визначити ділянки соляного масиву, перспективні для розміщення виробок, призначених для експлуатації соляних ресурсів і розміщення приміщень підземної лікарні за критеріями зовнішньої і внутрішньої захищеності соляного масиву, як було показано вище, і якості сировини. Основним інформаційно-аналітичним засобом для вибору ділянок має бути удосконалена цифрова структурнолітологічна модель Солотвинської солянокупольної структури.

За інтерпретацією отриманих раніше даних вже зараз ми можемо надавати висновки щодо перспективності північно-західної частини соляного масиву. Для остаточного вибору ділянок і обгрунтування деяких заходів зі стабілізації екологічної ситуації необхідне проведення крупномасштабного цільового моделювання.

Висновки. Вищенаведений матеріал свідчить, що створення екологічно небезпечної ситуації на Солотвинському родовищі $є$ типовим випадком розвитку деструктивних явищ внаслідок порушення головних принципів забезпечення стійкості масиву, а саме, - тотального порушення зовнішньої захищеності соляної товщі при існуванні ділянок соляного масиву із незадовільною внутрішньою захищеністю. Формування надзвичайної ситуації проходило за класичною схемою розвитку карсту, яка завжди працює у створених умовах. Крім того, ситуація була ускладнена також певними порушеннями норм експлуатації в частині геологічного i наукового забезпечення проведення гірничих робіт.

Визначення стратегічних напрямків вирішення соціальних, виробничих і екологічних проблем можливе лише на основі науково обгрунтованого визначення ступеню захищеності соляної товщі i створюваної техногенної системи. Головну роль при цьому повинна виконувати комплексна геолого-екологічна модель родовища, основним підпорядкованим елементом якої $\epsilon$ структурно-літологічна модель (3 урахуванням техногенезу соляного масиву), аналіз якої визначає розповсюдження функціональних типів кам'яної солі і дозволяє визначити ділянки геологічного середовища, придатні для подальшого використання без негативних екологічних наслідків.

Припинення деструктивних явищ можливе лише після відродження стабільного гідрогеологічного режиму i відновлення певного рівня захищеності, і це може бути наслідком повного затоплення усіх виробок, що розкрили ділянки незадовільної захищеності, та підземних порожнин, гідравлічно пов'язаних з ними. Вважаючи складність проблеми, вирішення проблем Солотвино на теперішній час можливе лише на основі загальної Програми розв'язання екологічних, соціальних та виробничих проблем, яка буде базуватися на об'єктивній оцінці ситуації, що виникла.

За попередньою оцінкою, перспективними напрямками подальшого використання Солотвинської соляної товщі за умови вирішення екологічних проблем можуть бути наступні: створення нового спелеосанаторію, організація обмеженого видобування кам'яної солі 3 подальшою 
підготовкою підземних просторів для екскурсійно-розважального центру, заснування розсолопромислу.

\section{Бібліографічні посилання}

1. Босевская Л. П. Основные принципы инженерно-геологической оценки соляных массивов, использование их как среды для сооружения подземных объектов различного назначения / Л. П. Босевская // Вісник Дніпропетровського університету. Серія «Геологія. Географія». - Т. 18. - Випуск 12. - 2010. - № 3/2. - Дніпропетровськ: ДНУ. С. $95-105$.

2. Виконання досліджень з оцінки впливу діяльності соляних підприємств України на навколишнє природне середовище та розробка науково обгрунтованих рекомендацій i інженерних пропозицій щодо поліпшення екологічного стану територій соляних виробництв: закл. звіт / УкрНДІсіль; керівники роботи С. І. Міщенко, Л. П. Босевська; шифр роботи 95/4; № ДР 0108U006372. - Фонди УкрНДІсіль; арх. № 7125. - Артемівськ, 2009. - 185 c.

3. Виконати послуги 3 досліджень геолого-літологічних особливостей Солотвинського родовища кам'яної солі з метою експертного визначення та наукового обгрунтування можливості створення нового підземного відділення Української алергологічної лікарні : закл. звіт про НДР / УкрНДІсіль; керівник роб. Л. П. Босевська; шифр роботи 1072/09; № ДР 0110U003087. - Фонди УкрНДІсіль; інв. № 7152. - Артемівськ, 2010. - 118 с.

4. Доручення Президента України щодо врегулювання ситуації, що склалася на державному підприємстві «Солотвинський солерудник», збереження алергологічних лікарень, що функціонують у підземних виробках соляних шахт цього підприємства, та недопущення виникнення техногенної катастрофи у селищі Солотвино Тячівського району Закарпатської області [Електронний ресурс] // Президент України Віктор Янукович. Офіційне Інтернет-представництво. - 19.11.2010. - Режим доступу: http://www.president.gov.ua/documents/12492.html. - Назва з екрану.

5. Копыстянский Р.С. Проницаемость соленосных пород в связи с нефтегазоносностью // Условия образования и особенности нефтегазоносности солянокупольных структур. К.: Наукова думка, 1966. - С. 284-291.

6. Методологічні та практичні аспекти визначення захищеності соляних товщ / [Хрущов Д.П., Босевська Л.П., Кирпач Ю.В. та ін.] // Екологічна безпека: проблеми та шляхи вирішення : міжнародна наук.-практ. конф., Алушта, $7-11$ вер. 2009 р.) [зб. наук. статей у 2 томах]. - Х.: Р айдер, 2009. - Т. I, С. 99 - 104.

7. Під головуванням Першого заступника Міністра МНС Михайла Болотських відбулася міжвідомча нарада щодо ситуації на ДП «Солотвинський солерудник» [Електронний pecypc] / МНС України. Офіційний інформаційний сервер. Прес-центр МНС. 21.12.2010p. - Режим доступу: http://www.mns.gov.ua/news/17793.html _ - Назва 3 екрану.

8. Серая А. Р. Исследование прочностных свойств каменной соли Илецкого и Солотвинского месторождений / А.Р. Серая, П.Д. Левицкий, А.С. Щёголь // Техника и технология добычи и переработки поваренной соли. - Труды ВНИИсоль, вып. 17 (25). Артемовск, 1971. - с. 25 - 30. 11. Хрущов Д. П. Техногенне втручання в середовище соляних масивів: екологічні аспекти / Д. П. Хрущов, Л. П. Босевська, Ю. В. Кирпач // Геологічний журнал. - 2010. - № 2. - С. 38-46.

9. Цифрова модель Солотвинської солянокупольної структури / [Л. П. Босевська, Д. П. Хрущов, О. П. Лобасов, Ю. В. Кирпач] // Зб. наук. праць Інституту геологічних наук НАНУ. Випуск 3. - 2010. - С. $248-255$.

10. Хрущов Д. П. Принципы разработки цифровых структурно-литологических моделей осадочных формационных подразделений / Д. П. Хрущев, А. П. Лобасов // Геол. журн. 2006. - № 2-3. - С. 90-102. 
11. Cooper, Anthony H., 2005, Environmental problems caused by gypsum karst and salt karst in Great Britain: Carbonates and Evaporites, Vol 17, no 2, p. 116-120, DOI: 10.1007 / BF03176477.

12. Gutirrez, F, Johnson, Kenneth; Cooper, Anthony, 2008, Evaporite-karst processes, landforms, and environmental problems.Environmental Geology, 53 (5). 935-936.

Надійшла до редколегї 06.06.2011 